\title{
The Lake CHAd Deep DRILLing project (CHADRILL) - targeting $\sim 10$ million years of environmental and climate change in Africa
}

\author{
Florence Sylvestre $^{1}$, Mathieu Schuster ${ }^{2}$, Hendrik Vogel $^{3}$, Moussa Abdheramane ${ }^{4}$, Daniel Ariztegui ${ }^{5}$, \\ Ulrich Salzmann $^{6}$, Antje Schwalb ${ }^{7}$, Nicolas Waldmann ${ }^{8}$, and the ICDP CHADRILL Consortium* \\ ${ }^{1}$ Aix-Marseille Université, CNRS, IRD, Collège de France, INRA, CEREGE, \\ Europôle de l'Arbois, 13545 Aix-en-Provence, France \\ ${ }^{2}$ Université de Strasbourg, CNRS, Institut Physique du Globe de Strasbourg, \\ 1 rue Blessig, 67084 Strasbourg, France \\ ${ }^{3}$ University of Bern, Institute of Geological Sciences \& OCCR, Baltzerstr. 1+3, Bern 3012, Switzerland \\ ${ }^{4}$ Université de N'Djamena, Faculté des Sciences Exactes et Appliquées, Route de Farcha, N'Djamena, Tchad \\ ${ }^{5}$ University of Geneva, Department of Earth Sciences, rue des Maraichers 13, Geneva 1205, Switzerland \\ ${ }^{6}$ University of Northumbria, Department of Geography and Environmental Sciences, 2 Ellison Place, \\ Newcastle upon Tyne, NE1 8ST, UK \\ ${ }^{7}$ Technische Universtät Braunschweig, Institute of Geosystems and Bioindication, \\ Langer Kamp 19c, Braunschweig 38114, Germany \\ ${ }^{8}$ University of Haifa, Department of Marine Geosciences, Mt. Carmel, Haifa, Israel \\ *A full list of authors and their affiliations appears at the end of the paper.
}

Correspondence: Florence Sylvestre (sylvestre@ cerege.fr)

Received: 14 November 2017 - Revised: 29 January 2018 - Accepted: 2 February 2018 - Published: 22 October 2018

Abstract. At present, Lake Chad $\left(\sim 13^{\circ} \mathrm{N}, \sim 14^{\circ} \mathrm{E}\right)$ is a shallow freshwater lake located in the Sahel/Sahara region of central northern Africa. The lake is primarily fed by the Chari-Logone river system draining a $\sim 600000 \mathrm{~km}^{2}$ watershed in tropical Africa. Discharge is strongly controlled by the annual passage of the intertropical convergence zone (ITCZ) and monsoon circulation leading to a peak in rainfall during boreal summer. During recent decades, a large number of studies have been carried out in the Lake Chad Basin (LCB). They have mostly focused on a patchwork of exposed lake sediments and outcrops once inhabited by early hominids. A dataset generated from a $673 \mathrm{~m}$ long geotechnical borehole drilled in 1973, along with outcrop and seismic reflection studies, reveal several hundred metres of Miocene-Pleistocene lacustrine deposits.

CHADRILL aims to recover a sedimentary core spanning the Miocene-Pleistocene sediment succession of Lake Chad through deep drilling. This record will provide significant insights into the modulation of orbitally forced changes in northern African hydroclimate under different climate boundary conditions such as high $\mathrm{CO}_{2}$ and absence of Northern Hemisphere ice sheets. These investigations will also help unravel both the age and the origin of the lake and its current desert surrounding. The LCB is very rich in early hominid fossils (Australopithecus bahrelghazali; Sahelanthropus tchadensis) of Late Miocene age. Thus, retrieving a sediment core from this basin will provide the most continuous climatic and environmental record with which to compare hominid migrations across northern Africa and has major implications for understanding human evolution. Furthermore, due to its dramatic and episodically changing water levels and associated depositional modes, Lake Chad's sediments resemble maybe an analogue for lake systems that were once present on Mars. Consequently, the study of the subsurface biosphere contained in these sediments has the potential to shed light on microbial biodiversity present in this type of depositional environment.

We propose to drill a total of $\sim 1800 \mathrm{~m}$ of poorly to semi-consolidated lacustrine, fluvial, and eolian sediments down to bedrock at a single on-shore site close to the shoreline of present-day Lake Chad. We propose to locate 
our drilling operations on-shore close to the site where the geotechnical Bol borehole $\left(13^{\circ} 28^{\prime} \mathrm{N}, 14^{\circ} 44^{\prime} \mathrm{E}\right)$ was drilled in 1973. This is for two main reasons: (1) nowhere else in the Chad Basin do we have such detailed information about the lithologies to be drilled; and (2) the Bol site is close to the depocentre of the Chad Basin and therefore likely to provide the stratigraphically most continuous sequence.

1

Covering almost $8 \%$ of the continent, the Lake Chad Basin (LCB) is the largest endhoreic drainage basin in Africa $\left(2.5 \times 10^{6} \mathrm{~km}^{2}\right)$ and one of the largest intracratonic basins on Earth (Fig. 1). Formation of accommodation space started during the Cenozoic (Burke, 1976) with nearly continuous deposition of terrestrial/lacustrine sediments since $\sim 10 \mathrm{Myr}$ (Lebatard et al., 2008; Schuster et al., 2009). Today's Lake Chad is a terminal and highly variable shallow freshwater lake ( $\sim 3 \mathrm{~m}$ deep, measured in 2012$)$ with a strong S-to-N conductivity gradient (50 to $700 \mu \mathrm{S} \mathrm{cm}^{-1}$; Bouchez et al., 2016). The annual invigoration of the northern African monsoon system and migration of the intertropical convergence zone (ITCZ) results in a short rainy season from June to October and a pronounced dry season for the rest of the year. During recent decades, the lake level varied by up to $4 \mathrm{~m}$, with a highstand in the 1960s, a prolonged lowstand in the 1970s, and a recovery phase since the beginning of the 2000s, thus emphasizing that lake-level changes reflect regional changes in rainfall (Lebel and Abdou, 2009). The latter together with its location at the interface of the African tropics and subtropics make the LCB sediment record a promising target to trace back changes in moisture variability in northern Africa under very different climate boundary conditions. Reconstructing the region's moisture variability since the Miocene would provide a very detailed picture of the environmental response to climate states with high atmospheric greenhouse gas (GHG) concentrations and limited Northern Hemisphere ice-sheet extent. This includes fundamental insights into the strength of modulation of orbitally forced changes in monsoon intensity and the effect of changes in ITCZ shifts/expansion under climate conditions common to the pre-Pleistocene. In addition, providing a glimpse into periods when both GHG concentrations and orbital parameters were similar to today will allow us to better constrain the impact of possible near-future climate states on the regional environment and societies. Such a study is timely given the enormous importance of today's lake as a freshwater and food source for $\sim 47$ million people (Lemoalle and Magrin, 2014) and the region's recent history of conflict.

With the discovery of several hominin remains associated with a rich fauna (Brunet et al., 1995, 2002), the LCB has been recognized as one of the cradles of humanity. Hominin remains, from the LCB and elsewhere in northern Africa (Hublin et al., 2017), demonstrate that the emergence of humans was not restricted to the East African Rift region. These discoveries not only raise important questions about the origin of humankind, but also strengthen the debate concerning the environmental triggers, such as precipitation variability, which may have impacted human evolution (Blome et al., 2012; Shultz and Maslin, 2013). A spatially better resolved picture of climate forced changes in environmental conditions and habitability in regions outside the rift valley is therefore required to elucidate their role in the evolution of modern humans. Until recently, it was considered that the $\mathrm{Sa}-$ hara was a natural obstacle to human migration, with the Nile as the only optimal corridor allowing northwards passage from the African tropics. Nevertheless, some studies show that the Sahara was probably not a continuous barrier and that both animals and humans may have populated the region during past humid phases known as Green Sahara Episodes (Larrasoaña et al., 2013). Other evidence even suggests a potential link between the Mediterranean Sea and the LCB via the ancient Esohabi River system in Libya, emphasizing the central Sahara as an alternative potential route for hominin dispersal (Griffin, 2006; Osborne et al., 2008; Drake et al., 2010).

The role of climate in the evolution and dispersal of hominid ancestors was probably amplified during the Tortonian (11.6-7.2 Myr), when shrinkage of the Tethys is thought to have been the main driver for the increasing aridity of Africa and formation of the Sahara (Zhang et al., 2014). As a consequence, the sensitivity of the African monsoon system to orbital forcing increased, making it the predominant driver for the cyclic expansion and contraction of the Sahara (Tuenter et al., 2003). However, there are some outstanding questions that are still debated, such as the timing of the formation of the Sahara. Both marine (Atlantic Ocean, Ruddiman and Janecek, 1989; Mediterranean Sea, Rose et al., 2016) and continental records (Chad Basin; Schuster et al., 2006) suggest a Late Miocene timing (close to the end of the Tortonian at $7 \mathrm{Myr}$ ), whereas other authors suggest that evidence prior to the onset of Northern Hemisphere glaciations at $\sim 3 \mathrm{Ma}$ (Swezey, 1999) is insufficient to support such a proposition.

Previous studies propose that the LCB was the source of the Esohabi River, a paleoriver system flowing northward from the southern Libyan desert down to the Mediterranean Sea during the Late Miocene (Griffin, 2006; Ghoneim et al., 2012). Although this river no longer flows today, climate models suggest that enhanced monsoonal rains in northern Africa fed it, and that it was roughly equivalent in size and magnitude to the present-day Nile (Gladstone et al., 2007). The freshwater flux influenced not only the immediate envi- 

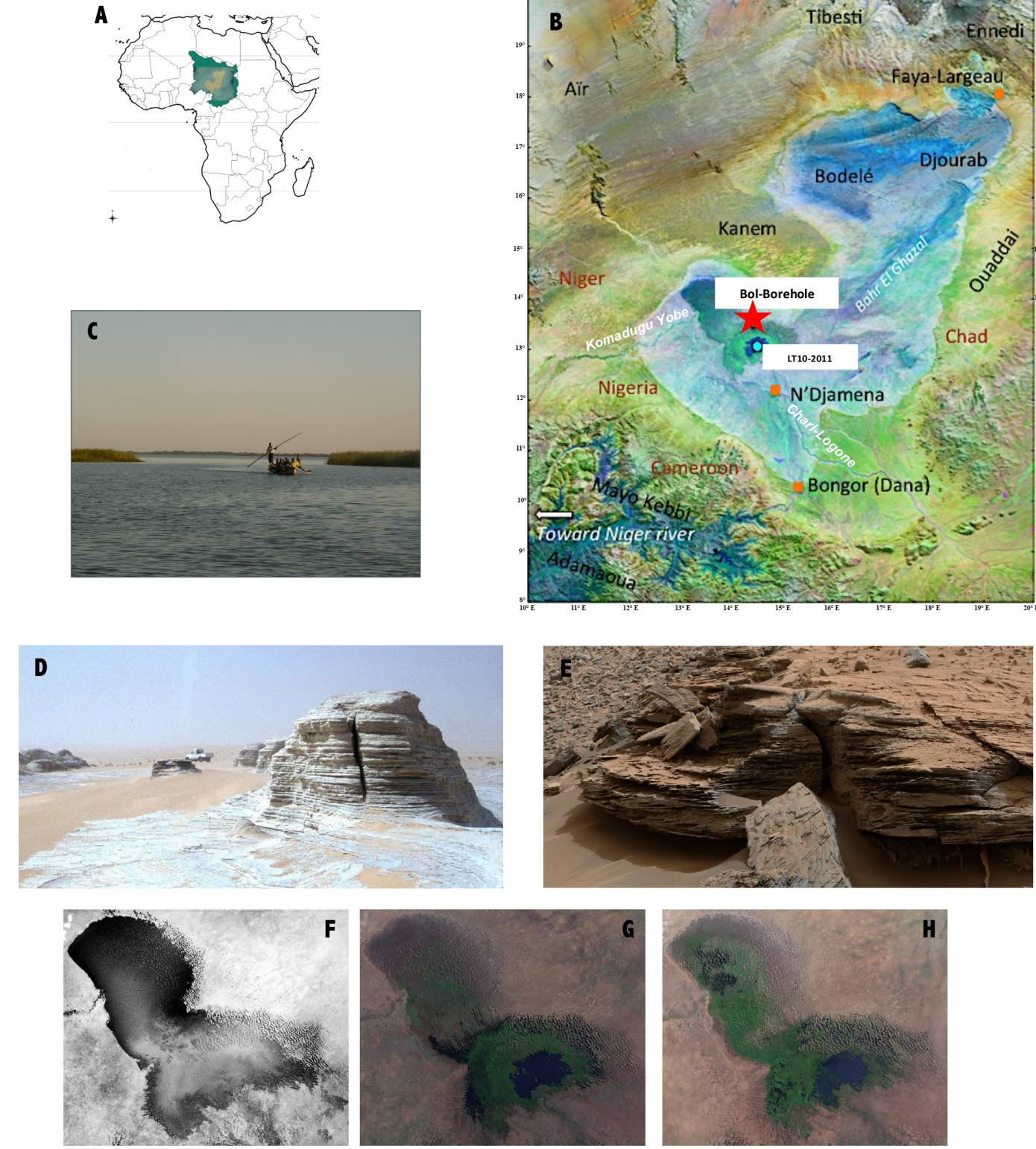

Figure 1. (a) Political map of Africa showing the Lake Chad hydrological basin. (b) SRTM map of the region surrounding Lake Chad. The shaded blue area marks the extension of the mega Lake Chad during the Holocene with an area of $34 \times 10^{4} \mathrm{~km}^{2}$. The principal populated towns are marked by red squares. The blue circle indicates the location of the previous core (LT10-2011) and the red star the borehole at Bol. (c) Picture of fishermen from Lake Chad. (d) Diatomite-dominated sequences deposited during previous transgressive episodes of Lake Chad currently outcropping in the Djourab region (see Fig. 1b for the location). The sediments date back to Holocene diatomites (Schuster et al., 2009). (e) Sediments of Mars (Rover pictures). Landsat images show the extension of the lake in 1963 (f), 1987 (g), and 2003 (h).

ronmental conditions of the Mediterranean region, but also may have been a driver of Mediterranean-Atlantic exchange and hence North Atlantic thermohaline circulation (Bryden and Kinder, 1991). Consequently, the record preserved in Lake Chad has implications for a climate system that spans half the globe, and is a critical transfer mechanism for water, salt, heat and nutrients from the equatorial to polar latitudes.

Our vision to obtain long sedimentary records from the LCB will also assess the dynamics of intracontinental basins through time and space. Sediments outcropping around Lake Chad show intriguing similarities to those discovered by the ongoing Curiosity Mars mission (Fig. 1e). This striking similarity makes the LCB a promising analogue for similar freshwater systems that were once present on Mars. Studying the subsurface biosphere in combination with in-depth investigation of associated diagenetic processes has the potential to provide valuable insights into the present query of early life on Earth and other planets. The strategy that NASA 


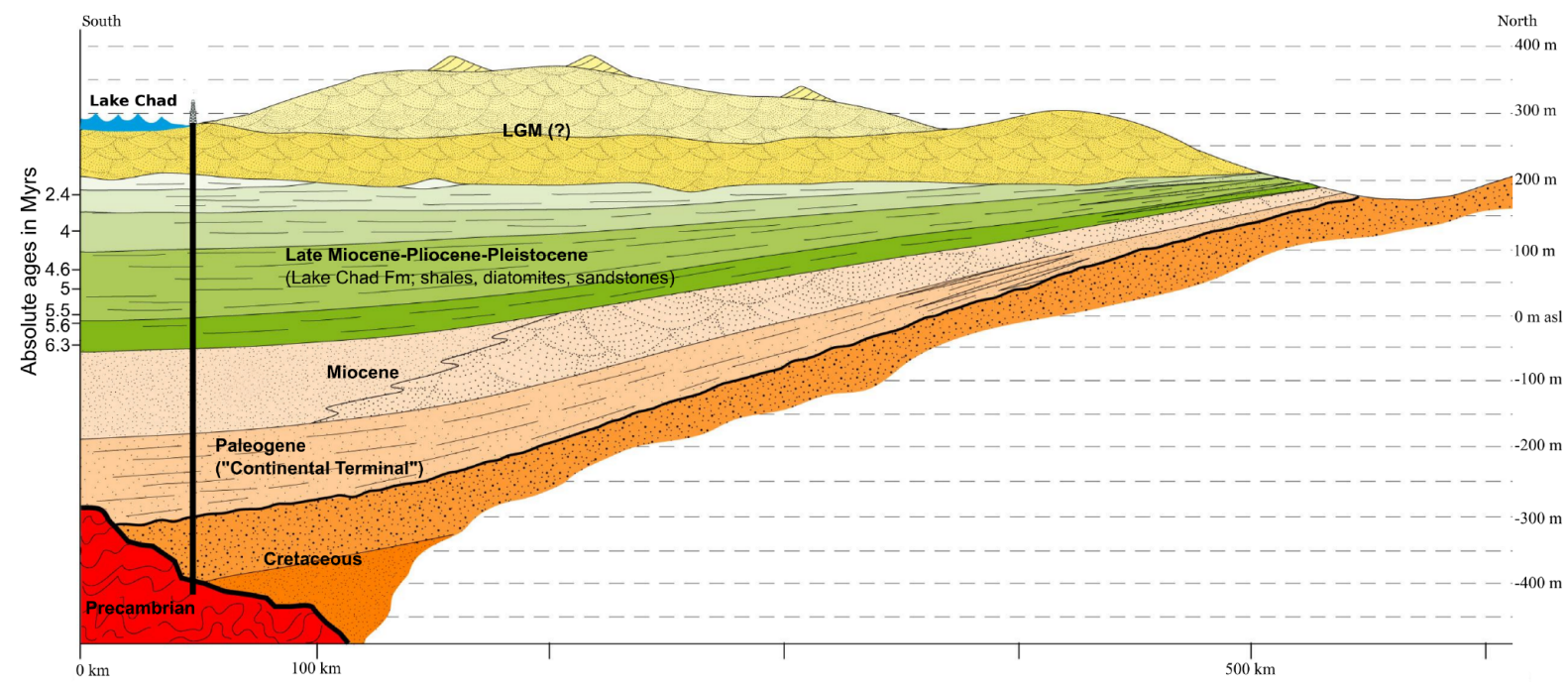

Figure 2. Synthetic and interpretative N-S geological transect across the Chad Basin showing the lateral extent and thickness of palaeo-Lake Chad beds (modified from Moussa, 2010).

will use during the already scheduled missions looking for signs of extra-terrestrial life will put special emphasis on microbially influenced sedimentary structures. These kinds of structures can be potentially recognized in the Lake Chad cores and compared to those identified with the new generation of instruments that will be sent to Mars in 2020. Among them a Close-UP Imager called CLUPI has been developed at the Space Exploration Institute (Space-X) of Neuchâtel, Switzerland, and will look at the subsurface of Mars through coring (Tomaso Bontognali, personal communication, 2017).

\section{Workshop structure and outcomes}

In view of the enormous opportunity for a scientific drilling project to investigate the sedimentary record of the LCB, an ICDP-sponsored workshop was organized in Aix-enProvence from 21 to 23 September 2016. Overall, 51 scientists and government officials from 11 countries (Belgium, Cameroon, Chad, France, Germany, Israel, Nigeria, Spain, Switzerland, UK and USA) participated in the discussion that framed the scientific objectives as well as challenges associated with the technical and logistical aspects of an ICDP drilling project in the LCB.

The workshop commenced with a full day of presentations on the key science themes, results from ongoing and previous research in the LCB, as well as broader overview talks on the northern African climate evolution since the Miocene and the associated responses of the biosphere. Participants paid particular attention to the presentations on sedimentological, chronological, and paleoenvironmental datasets obtained from a $673 \mathrm{~m}$ deep geotechnical borehole that reached bedrock at an on-shore site close to the city of Bol on the north-eastern shore of Lake Chad (Figs. 1 and 2), consid- ered the depocentre of the LCB (Burke, 1976). Datasets obtained from core cuttings and drill logs emphasize the presence of $\sim 600 \mathrm{~m}$ thick Miocene to Early Pleistocene deposits composed of fine-grained terrestrial deposits below a $\sim 70 \mathrm{~m}$ thick succession of Late Pleistocene dune sands (Fig. 3). Deposits in the succession between $\sim 70$ and $300 \mathrm{~m}$, where core cuttings are available, comprise fine-grained muds, diatomaceous oozes, and diatomites with structures ranging from massive to finely laminated (Moussa et al., 2016). Authigenic ${ }^{10} \mathrm{Be}$ burial dating (Lebatard et al., 2010) along with biostratigraphic constraints (Novello et al., 2015) place this succession between $6.3 \mathrm{Myr}(\sim 300 \mathrm{~m}$ depth$)$ and $2.4 \mathrm{Myr}(\sim 90 \mathrm{~m}$ depth$)$. These deposits thus represent nearly continuous sedimentation in a lacustrine setting similar to today's Lake Chad. Chronological as well as detailed lithological information is not available from the lower succession ( 300-673 m) due to the lack of core cuttings. However, drill logs from the lower succession suggest that fine-grained lacustrine muds and diatomaceous oozes, though more often intercalated with more extensive sand-sized deposits, prevail (Moussa et al., 2016).

Other stratigraphic information from exploration boreholes in Chad and Nigeria indicates either more condensed lacustrine successions or depositional environments with a stronger influence of deltaic processes (especially to the south). Outcrop studies undertaken in the northern Chad Basin emphasize the stronger influence of deflation at potential drill sites. The deep structure of the Chad Basin (i.e. location of the basement and thickness of sedimentary infill), synthesized in Servant-Vildary (1973), Burke (1976) and Servant (1983), is, notably, based on the geophysical characterization (e.g. gravimetry, isostacy) produced by Louis (1970) as well as on available data from exploration boreholes. To- 


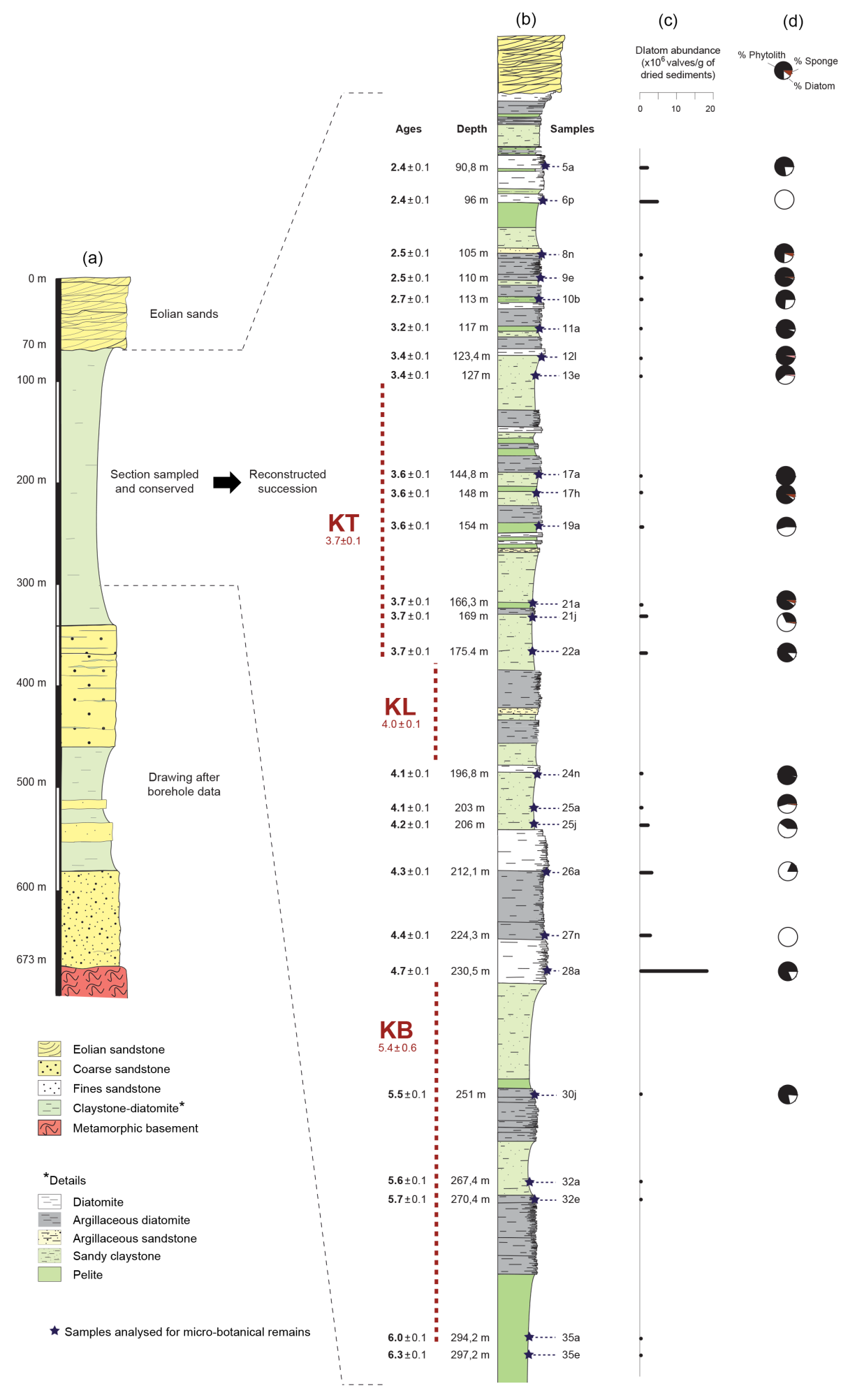

Figure 3. Sedimentology of the Bol borehole, chronology and stratigraphical positions of the 25 samples studied in detail (from Novello et al., 2015) with (a) general lithological succession of the whole core and ${ }^{10}$ Be chronology (the position of the Mio-Pliocene fossil sites from Djourab is located in parallel to the chronology of the borehole), (b) a detailed sequence reconstructed from preserved cuttings, (c) diatom concentration in the studied samples (number of valves/g dry sediments), and (d) quantification of phytoliths, diatoms and sponge spicules recovered in the silicified assemblages (Novello et al., 2015; Moussa et al., 2016). 
gether, these data suggest that the thickest accumulation of sediment occurred in the vicinity of present-day Lake Chad. There, the infill of the basin is documented by several shallow to deep boreholes (Roche, 1973; Servant, 1983). Among the seven deep boreholes published by Servant (1983; see Fig. 13), the one done in Bol shows the thickest sedimentary succession.

Based on these data and recent studies on core cuttings from the Bol exploration borehole (Novello et al., 2015; Moussa et al., 2016), the participants targeted the Bol site as the most promising location for obtaining a long and more continuous record from the LCB. This decision, based on the scientific value of the site, was strongly supported by Chadian government officials, who emphasized the site's accessibility and local infrastructure suitable for hosting a scientific drilling operation.

The second day was dedicated to topical break-out group discussions targeting the main thematic and disciplinary aspects and aimed at developing detailed scientific objectives and strategies capable of reaching major research goals. In addition, discussions elaborated the scientific working programme, and identified synergies between different groups, proxies, and analytic methodologies to be applied to reach the research goals. During the final day's morning session, funding strategies were developed, responsibilities were allotted, and a timeline for reaching milestones towards the realization of a comprehensive scientific drilling programme in the LCB was established. We also intensively discussed security in the field, which constitutes one of the greatest challenges for CHADRILL drilling operations. Because of our strong support by the Chadian authorities, we will be able to determine the best window for planning and executing the CHADRILL drilling operation. Last, but not least, one important aspect of the CHADRILL project is capacity building and the societal benefits of the proposed work. We dedicated a plan for involving students for Chad and the countries bordering the lake in our programme. Moreover, the first avenue for education and outreach is communicating knowledge to government authorities and other stakeholders (public and private). Lake Chad is central to the economic development of the region. This drilling project will contribute to a better understanding of water-resource availability, which is essential for long-term economic development and stability in the region.

As a result of the break-out group discussions, the workshop participants formulated what would be the major scientific objectives of a CHADRILL scientific drilling programme. In summary, long sediment drill cores from the LCB will allow us to:

- document the mechanisms by which orbital forcing, continental ice-sheet volume/extent, and changing atmospheric $\mathrm{CO}_{2}$ concentration influence northern African climate and environment;
- identify the climatic context that shaped environmental conditions favourable for human dispersal into northern Africa;

- identify the depositional context of the early stages of basin formation and explore the possible link to the Mediterranean Sea;

- provide valuable information on the origin of the Sahara and the evolution of ecological diversity across multiple vegetation zones;

- explore the limit of the deep biosphere and the factors controlling the abundance and activity of microbes in the sediments;

- and put recent hydrological changes in Lake Chad into the context of its long-term evolution with a view to evaluating its sustainability and that of the societies it supports.

In order to meet these objectives, drilling will be performed at a location close to the site where the geotechnical borehole was drilled in the 1970s. The primary target of CHADRILL operations would be to recover a complete succession of the lacustrine deposits present between $\sim 70$ and $300 \mathrm{~m}$ depth. Secondary targets will focus on the recovery of sediments from the lower $(\sim 300-670 \mathrm{~m}$ depth $)$ succession of more heterogeneous lacustrine deposits, and upper (0-70 m depth) dune sands. The envisaged CHADRILL research programme would thus complement previously accomplished and upcoming ICDP co-sponsored lake-drilling projects on the African continent and help to complete the vision of a dense global network of continental paleoclimate records that elucidate how climatic change altered the environment on local to regional scales. A CHADRILL record would furthermore form an excellent tandem with the envisioned recovery of palaeoclimate records from Lake Tanganyika. Both records are proposed to extend timescales back to the Miocene, north and south of the Equator, thus offering unprecedented insight into the climatically and geodynamically driven ecosystem evolution of the continent.

Data availability. No data sets were used in this article.

Team list. Olusegun Adeaga (Nigeria, University of Lagos), Dave Ahounta (Chad, CNRD), Mike Akaegbobi Izuchukwu (Nigeria, University of Ibadan), Likius Andossa (Chad, University of N'Djamena), Daniel Ariztegui (Switzerland, University of Geneva), Simon Armitage (United Kingdom, University of London), Laurent Augustin (France, CNRS/INSU/DT), Doris Barboni (France, CEREGE), Edouard Bard (France, CEREGE), Melissa Berke (USA, University of Notre Dame), Camille Bouchez (France, CEREGE), Didier Bourlès (France, CEREGE), Charles Bristow (United Kingdom, University of London), Eric Brown (USA, University of Minnesota Duluth), Christopher Campisano (USA, 
Arizona State University), Françoise Chalié (France, CEREGE), Leon Clarke (United Kingdom, Manchester Metropolitan University), Camille Contoux (France, CEREGE), Martine Couapel (France, CEREGE), Doriane Delanghe (France, CEREGE), Pierre Deschamps (France, CEREGE), Jean-Claude Doumnang (Chad, University of N'Djamena), Rachel Flecker (United Kingdom, Bristol), Uli Harms (Germany, Potsdam), Jonathan Holmes (United Kingdom, University College London), Reuben Ikhane Phillips (Nigeria, Olabisi Onabanjo University), Moussa Isseini (Chad, University of N'Djamena), Guillaume Jouve (France, CEREGE), Juan Larrasoana (Spain, Inst. Geológico y Minero de España), Anne-Elisabeth Lebatard (France, CEREGE), Suzanne Leroy (France, CEREGE), Youssouf Mahamoud (Chad, CNRD), Abdheramane Moussa (Chad, University of N'Djamena), Dennis Nielson (USA, DOSECC), François Nguetsop (Cameroon, University of Tchang), Reginald C. Njokuocha (Nigeria, University of Nigeria), Anders Noren (USA, University of Minnesota), Naomi Porat (Israel, Geological Survey of Israel), Poulin Chloé (France, CEREGE), Ulrich Salzmann (United Kingdom, Northumbria University), Lisa Schüler-Goldbach (Germany, Göttingen University), Mathieu Schuster (France, IPGS - University of Strasbourg), Florence Sylvestre (France, CEREGE), Kazuyo Tachikawa (France, CEREGE), Nicolas Thouveny (France, CEREGE), Benjamin Tutolo (United Kingdom, University of Oxford), Dirk Verschuren (Belgium, University of Ghent), Laurence Vidal (France, CEREGE), Finn Viehberg (Germany, University of Cologne), Hendrik Vogel (Switzerland, University of Bern), and Nicolas Waldmann (Israel, University of Haifa)

Competing interests. The authors declare that they have no conflict of interest.

Acknowledgements. The CHADRILL science team thanks the ICDP for supporting the planning workshop that aided in formulating and designing our envisaged research and drilling programme. We would also like to thank an anonymous reviewer and Andy Cohen for their constructive reviews that greatly improved this workshop report.

Edited by: Thomas Wiersberg

Reviewed by: Andrew S. Cohen and one anonymous referee

\section{References}

Blome, M. W., Cohen, A. S., Tryon, C. A., Brooks, A. S., and Russell, J.: The environmental context for the origins of modern human diversity: a synthesis of regional variability in African climate 150,000-30,000 years ago, J. Hum. Evol., 62, 563-592, 2012.

Bouchez, C., Goncalves, J., Deschamps, P., Vallet-Coulomb, C., Hamelin, B., Doumnang, J.-C., and Sylvestre, F.: Hydrological, chemical, and isotopic budgets of Lake Chad: a quantitative assessment of evaporation, transpiration and infiltration fluxes, Hydrol. Earth Syst. Sci., 20, 1599-1619, https://doi.org/10.5194/hess-20-1599-2016, 2016.
Brunet, M., Beauvilain, A., Coppens, Y., Heintz, E., Moutaye, A. H., and Pilbeam, D.: The first australopithecine 2500 kilometres west of the Rift Valley (Chad), Nature, 378, 273-275, 1995.

Brunet, M., Guy, F., Pilbeam, D., Mackaye, H. T., Likius, A., Ahounta, D., Beauvilain, A., Blondel, C., Bocherens, H., Boisserie, J. R., De Bonis, L., Coppens, Y., Dejax, J., Denys, C., Duringer, P., Eisenmann, V. R., Fanone, G., Fronty, P., Geraads, D., Lehmann, T., Lihoreau, F., Louchart, A., Mahamat, A., Merceron, G., Mouchelin, G., Otero, O., Campomanes, P. P., De Leon, M. P., Rage, J. C., Sapanet, M., Schuster, M., Sudre, J., Tassy, P., Valentin, X., Vignaud, P., Viriot, L., Zazzo, A., and Zollikofer, C.: A new hominid from the Upper Miocene of Chad, central Africa, Nature, 418, 145-151, 2002.

Bryden, H. L. and Kinder, T. H.: Steady 2-layer exchange through the strait of gibraltar, Deep-Sea Res Pt. 1, 38, S445-S463, 1991.

Burke, K.: The Chad Basin: an active intra-continental basin, Tectonophysics, 36, 197-206, 1976.

Drake, N. A., Blench, R. M., Armitage, S. J., Bristow, C. S., and White, K. H.: Ancient watercourses and biogeography of the Sahara explain the peopling of the desert, P. Natl. Acad. Sci. USA, 108, 458-462, 2010.

Ghoneim, E., Benedetti, M., and El-Baz, F.: An integrated remote sensing and GIS analysis of the Kufrah Paleoriver, Eastern Sahara, Geomorphology, 139, 242-257, 2012.

Gladstone, R., Flecker, R., Valdes, P., Lunt, D., and Markwick, P.: The Mediterranean hydrologic budget from a Late Miocene global climate simulation, Palaeogeogr. Palaeocl., 251, 254-267, https://doi.org/10.1016/j.palaeo.2007.03.050, 2007.

Griffin, D. L.: The late Neogene Sahabi rivers of the Sahara and their climatic and environmental implications for the Chad Basin, J. Geol. Soc. London, 163, 905-921, 2006.

Hublin, J. J., Ben-Ncer, A., Bailey, S. E., Freidline, S. E., Neubauer, S., Skinner, M. M., Bergmann, I., Le Cabec, A., Benazzi, S., Harvati, K., and Gunz, P.: New fossils from Jebel Irhoud, Morocco and the pan-African origin of Homo sapiens, Nature, 546, 289292, 2017.

Larrasoaña, J. C., Roberts, A. P., and Rohling, E. J.: Dynamics of Green Sahara periods and their role in Hominin evolution, PLoS One, 8, e76514, https://doi.org/10.1371/journal.pone.0076514, 2013.

Lebatard, A.-E., Bourlès, D. L., Duringer, P., Jolivet, M., Braucher, R., Carcaillet, J., Schuster, Arnaud, N., Monié, P., Lihoreau, F., Likius, A., Mackaye, Hassan, T., Vignaud, P., and Brunet, M.: Cosmogenic nuclide dating of Sahelanthropus tchadensis and Australopithecus bahrelghazali: Mio-Pliocene hominids from Chad, P. Natl. Acad. Sci. USA, 105, 3226-3231, 2008.

Lebatard, A.-E., Bourlès, D. L., Braucher, R., Arnold, M., Duringer, P., Jolivet, M., Moussa, A., Deschamps, P., Roquin, C., Carcaillet, J., Schuster, M., Lihoreau, F., Likius, A., Mackaye, H. T., Vignaud, P., and Brunet, M.: Application of the authigenic $10 \mathrm{Be} / 9 \mathrm{Be}$ dating method to continental sediments: Reconstruction of the Mio-Pleistocene sedimentary sequence in the early hominid fossiliferous areas of the northern Chad Basin, Earth Planet. Sc. Lett., 297, 57-70, 2010.

Lebel, T. and Abdou, A.: Recent trends in the Central and Western Sahel rainfall regime (1990-2007), J. Hydrol., 375, 52-64, 2009.

Lemoalle, J. (dir.) and Magrin, G. (dir.): Le développement du Lac Tchad : situation actuelle et futurs possibles : expertise collégiale réalisée par l'IRD à la demande de la Commission du 
Lac Tchad, Contributions intégrales des experts, Marseille, IRD, 1633-9924, 79-92, Expertise Collégiale; 1633-9924, ISBN 9782-7099-1836-7, 2014.

Louis, P.: Contribution géophysique à la connaissance géologique du Lac Tchad, Mem. O.R.S.T.O.M., 42, 311 pp., 1970.

Moussa, A.: Les series sédimentaires fluviatiles, lacustres et éoliennes du bassin du Tchad depuis le Miocène terminal, Ph.D thesis, Université de Strasbourg, 249 pp., 2010.

Moussa, A., Novello, A., Lebatard, A. E., Decarreau, A., Fontaine, C., Barboni, D., Sylvestre, F., Bourlès, D. L., Paillès, C., Buchet, G., Duringer, P., Ghienne, J. F., Maley, J., Mazur, J. C., Roquin, C., Schuster, M., Vignaud, P., and Brunet, M.: Lake Chad sedimentation and environments during the late Miocene and Pliocene: New evidence from mineralogy and chemistry of the Bol core sediments, J. Afr. Earth Sci., 118, 192-204, 2016.

Novello, A., Lebatard, A.-E., Moussa Abderamane, Barboni, D., Sylvestre, F., Bourlès, D. L., Paillès, C., Buchet, G., Decarreau, A., Duringer, P., Ghienne, J.-F., Maley, J., Mazur, J.-C., Roquin, C., Schuster, M., and Vignaud, P.: Micro-botanical investigations on a new $10 \mathrm{Be} / 9 \mathrm{Be}$ dating lacustrine record from Chad: new insight on the Mio-Pliocene paleoenvironmental changes in Central Africa, Palaeogeogr. Palaeocl., 430, 85-103, 2015.

Osborne, A. H., Vace, D., Rohling, E. J., Rogerson, M., and Fello, N.: A humid corridor across the Sahara for the migration of early modern humans out of Africa 120,000 years ago, P. Natl. Acad. Sci. USA, 43, 16444-16447, 2008.

Roche, M. A.: Traçage naturel salin et isotopique des eaux du système hydrologique du lac Tchad, Ph.D Thesis, ORSTOM, Paris, France, 398 pp., 1973.

Rose, C., Polissar, P. J., Tierney, J. E., Filley, T., and deMenocal, P. B.: Changes in northeast African hydrology and vegetation associated with Pliocene-Pleistocene sapropel cycles, Philosophical Transactions Royal Society B, 371, 20150243, https://doi.org/10.1098/rstb.2015.0243, 2016.
Ruddiman, W. F. and Janecek, T. R.: Pliocene-Pleistocene biogenic and terrigenous fluxes at equatorial Atlantic Sites 662, 663, and 664, in: Proceedings of the Ocean Drilling Program, Scientific Results, edited by: Ruddiman, W., Sarnthein, M., et al., College Station, TX (Ocean Drilling Program), 108, 211-240, https://doi.org/10.2973/odp.proc.sr.108.165.1989, 1989.

Schuster, M., Duringer, P., Ghienne, J. F., Vignaud, P., Mackaye, H. T., Likius, A., and Brunet, M.: The age of the Sahara Desert, Science, 311, 821-821, 2006.

Schuster, M., Duringer, P., Ghienne, J. F., Roquin, C., Sepulchre, P., Moussa, A., Lebatard, A.-E., Mackaye, H. T., Likius, A., Vignaud, P., and Brunet, M.: Chad Basin: Paleoenvironments of the Sahara since the Late Miocene, Comptes Rendus Geosciences, 341, 612-620, 2009.

Servant, M.: Séquences continentales et variations climatiques : évolution du bassin du Tchad au Cénozoïque supérieur, Travaux et Documents ORSTOM, Paris, France, 573 pp., 1983.

Servant-Vildary, S.: Stratigraphie et néotectonique du PlioPléistocène ancien du Tchad d'après l'étude des diatomites, C. R. Acad. Sc. Paris, 276, 2633-2636, 1973.

Shultz, S. and Maslin, M. A.: Early human speciation, brain expansion and dispersal influenced by African climate pulses, PLoS ONE, 8, e76750, https://doi.org/10.1371/journal.pone.0076750, 2013.

Swezey, C. A.: A very old Sahara, Science, 286, 243-247, 1999.

Tuenter, E., Weber, S. L., Hilgen, F. J., and Lourens, L. J.: The response of the African summer monsoon to remote and localforcing due to precession and obliquity, Global Planet. Change, 36, 219-235, 2003.

Zhang, Z., Ramstein, G., Schuster, M., Li, C., Contoux, C., and Yan, Q.: Aridification of the Sahara desert caused by Tethys Sea shrinkage during the late Miocene, Nature, 513, 401-404, https://doi.org/10.1038/nature13705, 2014. 